Article

\title{
Biochars from Post-Production Biomass and Waste from Wood Management: Analysis of Carbonization Products
}

\author{
Wojciech Kosakowski ${ }^{1}$, Malgorzata Anita Bryszewska ${ }^{2, *}$ i] and Piotr Dziugan ${ }^{3}$ \\ 1 Polmos Żyrardów Sp. z o.o., ul. Mickiewicza 1-3, 96-300 Żyrardów, Poland; \\ wkosakowski@belvederevodka.pl \\ 2 Institute of Natural Products and Cosmetics, Faculty of Biotechnology and Food Sciences, Lodz University \\ of Technology, ul. Stefanowskiego 4/10, 90-924 Lodz, Poland \\ 3 Department of Environmental Biotechnology, Faculty of Biotechnology and Food Sciences, Lodz University \\ of Technology, Wolczanska 171/173, 90-924 Lodz, Poland; piotr.dziugan@p.lodz.pl \\ * Correspondence: malgorzata.bryszewska@p.lodz.pl; Tel.: +48-426-313-425
}

Received: 2 October 2020; Accepted: 31 October 2020; Published: 4 November 2020

check for updates

\begin{abstract}
Waste biomass can be used as an alternative source of energy. However, such use requires prior treatment of the material. This paper describes the physicochemical characteristics of biochar obtained by the thermochemical decomposition of six types of agricultural waste biomass: residues from the production of flavored spirits (a pulp of lime, grapefruit and lemon), beetroot pulp, apple pomace, brewer's spent grain, bark and municipal solid waste (bark, sawdust, off-cuts and wood chips). The biomass conversion process was studied under conditions of limited oxygen access in a reactor. The temperature was raised from 450 to $850{ }^{\circ} \mathrm{C}$ over $30 \mathrm{~min}$, followed by a residence time of $60 \mathrm{~min}$. The solid products were characterized in terms of their elemental compositions, mass, energy yield and ash content. The gaseous products from pyrolysis of the biomass were also analyzed and their compositions were characterized by GCMS (Gas Chromatography-Mass Spectrometry). The carbonization process increased the carbon content by, on average, 1.7 times, from an average percentage of $46.09 \% \pm 3.65 \%$ for biomass to an average percentage of $74.72 \% \pm 5.36 \%$ for biochars. After carbonization, the biochars were found to have a net calorific value of between 27 and $32 \mathrm{MJ} / \mathrm{kg}$, which is comparable or even higher than good-quality coal (eco pea coal $24-26 \mathrm{MJ} / \mathrm{kg}$ ). The net calorific values show that the volatile products can also be considered as a valuable source of energy.
\end{abstract}

Keywords: pyrolysis; biochars; agricultural waste; biomass

\section{Introduction}

Recycling biomass and various types of organic waste is a way of increasing the share of renewable sources in energy production [1]. The Sustainable Development Goals (SDGs) set out by the United Nations highlight renewable energy as key to the success of Agenda 2030 [1]. Possible sources of bioenergy include energy crops, biomass residues and organic wastes. However, direct use of biomass as a heat source may be inefficient and difficult. Complications may arise even at the storage stage, when high humidity is associated with microbiological biomass degradation. The co-combustion of biomass and coal can raise technical and economic issues. Wet biomass may cause instability in the combustion process itself. Incomplete combustion reduces the efficiency of the whole process and leads to energy losses. Incomplete combustion may also make it impossible to maintain the required emission parameters. Given the limited possibilities for using unprocessed biomass, pre-treatment is necessary to improve its energy properties. Various methods of initial biomass preparation are described in the literature, which enable co-combustion with coal in power boilers [2,3]. The process 
of thermal conversion of biomass to biofuel may include combustion, gasification, biocarbonization, torrefaction, dry distillation and pyrolysis [4-8].

Pyrolysis is a thermochemical treatment, involving the extensive thermal decomposition of organic material under oxygen-limited conditions or in an atmosphere of inert gases. The gas phase contains two kinds of compounds. The first are volatiles that condense and form a dark brown, viscous liquid phase. The second are volatile compounds with low molecular weight (e.g., $\mathrm{CO}, \mathrm{CO}_{2}, \mathrm{H}_{2}$, $\mathrm{CH}_{4}$ and light hydrocarbons). These non-condensable gases remain in the gas phase. The physical process and chemical reactions that occur in pyrolysis are highly complex, and both the conditions of pyrolysis and the organic matrix (which may originate from different sources) affect the quality of the biochar and its eventual properties. These parameters may be helpful when ranking waste materials as potential sources of biocarbon, and for assessing their suitability for co-firing. These parameters may also be used to evaluate the possibility of using condensing and non-condensing gas products for energy generation.

The aim of this research was to convert biomass into a biofuel with properties similar to those of coal. We used waste from the agricultural industry and municipal management as feedstock. The properties of biochars obtained by biomass carbonization were determined in single-factor experiments. We also characterized the main products of the gas products and condensates. The results could contribute to the development of strategies for biomass treatment and the reduction of emissions, improving the sustainability of biomass conversion processes at an industrial scale.

\section{Materials and Methods}

\subsection{Materials}

Six agricultural waste biomass materials were used in the study: flavored spirits production waste (FSW) (lime, grapefruit and lemon), apple pomace (A.pomace), beetroot pulp (B.pulp), brewer's spent grain (BSG), bark (pine bark) and municipal solid waste (bark, off-cuts, wood chips, sawdust (MSW)). The analyzed biomasses were pre-prepared by drying and grinding.

\subsection{Volatile Component Analysis}

Volatile component analysis was carried out with use of a GCMS (Gas Chromatography-Mass Spectrometry) (Termo Science Trace GC Ultra) and an RTX-1.60 $\mathrm{m} \times 0.25 \mathrm{~mm} \times 0.25 \mu \mathrm{m}$ capillary column (Restek, Saunderton, UK), combined with a DSQ-II (Dual-Stage Quadrupole) detector (Thermo Scientific, Austin, TX, USA). All the samples were analyzed in duplicate at a pyrolysis temperature of $550{ }^{\circ} \mathrm{C}$ with a heating rate of $20^{\circ} \mathrm{C} \mathrm{ms}^{-1}$. The samples were collected in Tedlar bags (Merck, Darmstadt, Germany Tedlar ${ }^{\circledR}$ PLV- Push Lock Valve Gas Sampling Bag).

\subsection{Moisture and Ash Content, Chemical Composition}

The total moisture content in the tested biomass was determined using the thermogravimetric approach. The materials were dried at $110^{\circ} \mathrm{C}$ until the complete removal of moisture. The ash content was determined using the slow ashing method, in which combustion and annealing of the analytical sample occurs in two stages, differing in temperature and duration. Dry ashing was performed in open inert crucibles in a muffle furnace. The samples $(1 \pm 0.1 \mathrm{~g}$ of biomass powdered by a broom mill) were placed in the cold furnace and combustion was performed with a constant increase in temperature up to $500^{\circ} \mathrm{C}$ for $30 \mathrm{~min}$. The temperature was gradually increased to $815^{\circ} \mathrm{C}$ over $30 \mathrm{~min}$. Complete ashing was achieved after thermal decomposition for $90 \mathrm{~min}$.

The chemical composition (content of carbon, sulfur, nitrogen) was determined using an elementary analyzer (CE Instruments, Milan, Italy.) and Eager 200 software (amlyzer type 2500), using methionine or BBOT (2,5-(bis(5-tert-butyl-2-benzo-oxazol-2-yl) thiophene) as the reference material. 


\subsection{Combustion Heat and Net Calorific Values, Energy Yield}

The calorific value was determined using a 6100 compensated jacket calorimeter (Parr Instruments $\mathrm{GmbH}$, Moline, IL, USA). Net calorific values were calculated on the basis of the amount of heat generated during the complete combustion of a mass unit $(1 \mathrm{~g})$ of biomass in an oxygen atmosphere using the formula

$$
\mathrm{LHV}=2.326 \times\left(\mathrm{HHV}-91.23 \times \mathrm{C}_{\mathrm{H}}\right)
$$

where LHV is the net calorific value (Lower Heating Value) $\left(\mathrm{J} / \mathrm{g}\right.$ ), $\mathrm{HHV}$ is the combustion heat and $\mathrm{C}_{\mathrm{H}}$ is the hydrogen content of the sample (\%) [9]. The net calorific value (LHV) of biomass is calculated as the heat of combustion reduced by the heat of water evaporation, obtained from the fuel in the process of combustion and from hygroscopic moisture. The energy densification ratio describes the ratio of the HHV of the dry product to the dry raw material.

$$
\text { Energy densification }=\mathrm{HHV}_{\text {biochar }} / \mathrm{HHV}_{\text {biomass }}
$$

The energy yields were calculated using the equation

$$
\text { Energy yield }=\left(\text { mass }_{\text {biochar }} / \text { mass }_{\text {biomass }}\right) \times\left(\mathrm{HHV}_{\text {biochar }} / \mathrm{HHV}_{\text {biomass }}\right) \times 100 \%
$$

Mass yields were calculated using the equation

$$
\text { Mass Yield }=\text { mass }_{\text {biochar }} / \text { mass }_{\text {biomass }}
$$

\subsection{Carbonization Process}

Thermal carbonization (pyrolysis) was performed in a CZYLOK reactor (Jastrzebie-Zdroj, Poland; model FCF 2R) modified in the laboratory to enable the collection of pyrolytic gases. An accurately weighed sample was placed in the oven at room temperature. Thermal decomposition was then performed under conditions of limited oxygen access. The temperature in the reactor was gradually increased to $850{ }^{\circ} \mathrm{C}$ over $30 \mathrm{~min}$. Pyrolysis was continued for $60 \mathrm{~min}$ at a constant temperature. Subsequently, the sample was left in the oven until the temperature fell. The solid residue after the process was weighed and stored for further analysis. The experiments were carried out in triplicate with seven gas collection points $\left(450,515,585,650,715,785\right.$ and $\left.850^{\circ} \mathrm{C}\right)$.

\section{Results}

\subsection{Physico-Chemical Properties and Chemical Composition of the Biomass}

The results from proximate and elemental analysis of all the waste samples are given in Table 1. The moisture contents of the tested biomasses in the working state were from $9.65 \%$ to $16.54 \%$. The lowest water content in the biomass was observed in waste from vodka production, which can be explained by the fact that these wastes had been dried in the factory before being delivered for analysis. The difference in the moisture content $(6.02 \%)$ between the bark samples and municipal waste was due to the weather conditions under which the biomasses had been processed and then stored.

The content of mineral substances was similar in most of the analyzed biomasses, ranging from $2.57 \%$ to $4.37 \%$. An exception was apple pomace, which contained only $1.05 \%$ of inorganic components. This value was in line with the data presented in the literature $[10,11]$. The ash content of MSW was in line with the average values described in the literature for wood biomass, in the range of $0.3-7.4 \%[12,13]$. These results also indicate that the samples were not contaminated with soil. Our values are much lower than those presented in the literature for coal, i.e., $5-45 \%$ ( $8.5-10.5 \%$ on average) [13]. The chlorine content in the analyzed biomass was in the range of $0.02-0.20 \%$ and such values are consistent with the literature data for woody biomass, the chlorine content of which 
ranges from $<0.005 \%$ to $0.057 \%$. In cultivated plants, the chlorine content may even be $>1.00 \%[2,14]$. High chlorine content in crops is often associated with the use of potassium fertilizer.

The total sulfur content was highest for agricultural crops, B.pulp $0.75 \%$, which probably results from the application of fertilizers for agrotechnical treatments. The nitrogen content was similar in all the analyzed biomasses $(1.35 \% \pm 0.26 \%$ ) and did not exceed $1.50 \%$, with the exception of BSG for which it was almost four-fold higher. However, this result is in accordance with the literature data, according to which the nitrogen content in crops can be up to $6.45 \%$. The high content of nitrogen in crops is correlated to their high content of proteins, which can represent up to $40 \%$ of the dry mass [2].

The bulk density of the analyzed biomasses varied widely, from 130 to $307 \mathrm{~kg} / \mathrm{m}^{3}$. This was lower than that of coal, which is on average in the range of $800-1000 \mathrm{~kg} / \mathrm{m}^{3}$. Low bulk density is uneconomical from the point of view of storage and transport. Therefore, biomass pre-treatment such as grinding, pressing or palletization should be considered.

\subsection{Characterization of Biochars}

\subsubsection{Morphology}

Applying pyrolysis to the waste biomass resulted in carbonization. Figure 1 presents graphical images of the biomass and the carbonized material. Carbonization occurred in the whole mass, and was as high on the surface as at the core. The transformations throughout the whole volume were probably a consequence of biomass fractionation, generated either by the production process (A.pomace, B.pulp, BSG) or by the grinding applied in this study (MSW, bark, FSW). Carbonization was not followed by major changes in the structure and mass density. The values for most of the carbonizates were similar to those determined for the biomass (Tables 1 and 2). An increase in mass density occurred only in two samples, apple pomace and MSW. These results are a consequence of pre-treatment, including grinding.

\subsubsection{Material and Energy Balance}

The material balances after pyrolysis were investigated using the gravimetric method. The results are presented in Figure 2. The solid residue (i.e., biochars) represented from $26.65 \%$ to $40.85 \%$ of the initial weight of the organic substance. However, this wide variation in yield was caused mainly by one sample, the bark. When the highest value is excluded, the values were very close, with a mean value of $27.98 \% \pm 2.08 \%$. The decrease in mass can be attributed to two causes. The first is moisture loss and the second is organic matter decomposition, with the formation of volatile products such as $\mathrm{CO}, \mathrm{CO}_{2}, \mathrm{CH}_{4}$ and many others. During the process of carbonization, variable amounts of liquid and gas products were formed, in proportions that depended on the biomass. Volatile matter, including water and both gas and oil fractions, composed up to $73 \%$ of the initial mass of the samples, with the exception of bark, in which these fractions comprised $59.15 \%$. These differences were probably due to the high content of hemicellulose, cellulose and lignin in bark.

The liquid fraction collected by condensation was composed of oil and water. Based on the mass of the liquid fraction, the oil fraction was calculated by diminishing the weight of the condensate by the moisture content. In general, the content of water was lower in the biomass from fruit waste (9.65\% FSW, $12.56 \%$ A.pomace). The highest value was obtained for biomass from bark $(16.54 \%)$. The greatest changes in the amounts of volatile compounds were recorded during heating up to $450{ }^{\circ} \mathrm{C}$.

Table 2 presents the results of proximate and elemental analysis of the biochars obtained from pyrolysis. The carbonization process increased the carbon content on average 1.7-fold, from an average percentage of $46.09 \% \pm 3.65 \%$ for biomass to an average percentage of $74.72 \% \pm 5.36 \%$ for carbonizates. As a consequence, the $\mathrm{C} / \mathrm{H}$ ratio also increased, reaching a value seven times higher. 


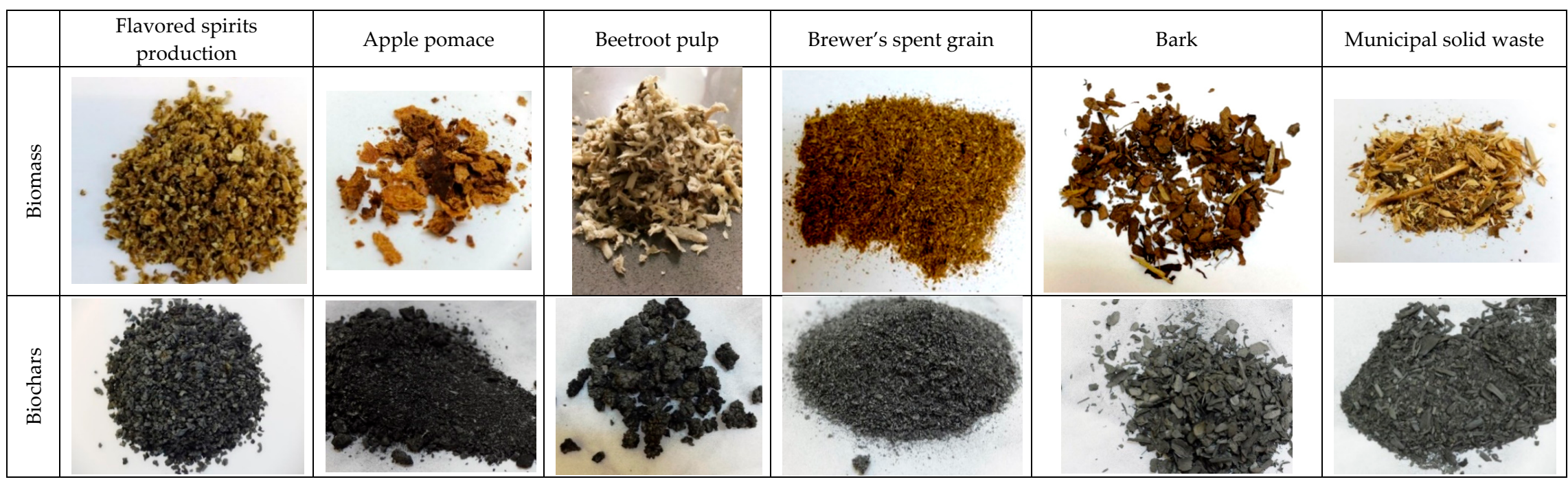

Figure 1. Photographs of the raw and carbonized materials. Thermal decomposition performed under conditions of limited oxygen access with gradually increased temperature up to $850^{\circ} \mathrm{C}$ over $30 \mathrm{~min}$ and continued for $60 \mathrm{~min}$ at a constant temperature. 
Table 1. Compositional and elemental analysis of biomass, expressed as average values ( \pm standard deviation). FSW-flavored spirits production waste (lime, grapefruit and lemon), B.pulp—beetroot pulp, A.pomace—apple pomace, BSG—brewer's spent grain, bark, MSW—municipal solid waste.

\begin{tabular}{|c|c|c|c|c|c|c|c|c|c|c|c|}
\hline \multirow{3}{*}{ Biomass } & \multirow{2}{*}{$\begin{array}{c}\text { Moisture } \\
\text { Content }\end{array}$} & \multirow{2}{*}{ Ash } & \multirow{2}{*}{$\begin{array}{c}\text { Values of } \\
\text { Combustion Heat }\end{array}$} & \multirow{2}{*}{$\begin{array}{l}\text { Net Calorific } \\
\text { Values }\end{array}$} & \multirow{2}{*}{ Mass Density } & \multicolumn{6}{|c|}{ Elemental Analysis } \\
\hline & & & & & & $\mathrm{C}$ & $\mathbf{H}$ & $\mathbf{N}$ & $\mathrm{S}$ & $\mathbf{O}$ & $\mathrm{Cl}$ \\
\hline & $(\%)$ & $(\%)$ & $(\mathrm{kJ} / \mathrm{kg})$ & $(\mathrm{kJ} / \mathrm{kg})$ & $\left(\mathrm{kg} / \mathrm{m}^{3}\right)$ & \multicolumn{6}{|c|}{$(\%)$} \\
\hline FSW & 9.65 & $3.85 \pm 0.34$ & $16.142 \pm 600$ & $14,904.3 \pm 553.8$ & $243.7 \pm 10.0$ & 41.94 & 5.83 & 1.32 & 0.42 & 37.24 & 0.09 \\
\hline A.pomace & 12.56 & $1.05 \pm 0.01$ & $21.229 \pm 135$ & $19,775.2 \pm 125.8$ & $155.2 \pm 9.3$ & 51.39 & 6.85 & 1.44 & 0.30 & 36.64 & 0.07 \\
\hline B.pulp & 12.33 & $2.93 \pm 0.02$ & $16.372 \pm 28$ & $15,169.2 \pm 25.8$ & $155.3 \pm 3.0$ & 41.83 & 5.67 & 1.32 & 0.75 & 35.50 & 0.20 \\
\hline BSG & 11.74 & $3.59 \pm 0.06$ & $20.288 \pm 59$ & $18,912.8 \pm 55.3$ & $290.1 \pm 11.6$ & 46.92 & 7.12 & 5.45 & 0.10 & 25.83 & 0.08 \\
\hline Bark & 16.54 & $4.37 \pm 0.10$ & $19.523 \pm 551$ & $18,477.1 \pm 521.5$ & $126.4 \pm 7.2$ & 47.23 & 6.30 & 1.18 & 0.18 & 39.94 & 0.03 \\
\hline MSW & 10.52 & $2.57 \pm 0.19$ & $18.744 \pm 104$ & $17,407.3 \pm 96.8$ & $130.2 \pm 10.1$ & 47.23 & 6.30 & 1.18 & 0.15 & 40.49 & 0.02 \\
\hline
\end{tabular}

Table 2. Compositional and elemental analysis of biochar, expressed as average values ( \pm standard deviation). FSW—flavored spirits production waste (lime, grapefruit and lemon), B.pulp—beetroot pulp, A.pomace—apple pomace, BSG—brewer's spent grain, bark, MSW—municipal solid waste, d.m. —dry mass.

\begin{tabular}{|c|c|c|c|c|c|c|c|c|c|c|}
\hline \multirow{3}{*}{ Biochars } & \multirow{2}{*}{$\begin{array}{l}\text { Mass } \\
\text { Yield }\end{array}$} & \multirow{2}{*}{ Ash } & \multirow{2}{*}{$\begin{array}{c}\text { Values of } \\
\text { Combustion Heat }\end{array}$} & \multirow{2}{*}{$\begin{array}{l}\text { Net Calorific } \\
\text { Values }\end{array}$} & \multirow{2}{*}{$\begin{array}{c}\text { Mass } \\
\text { Density }\end{array}$} & \multirow{2}{*}{$\begin{array}{c}\text { Energy } \\
\text { Densification Ratio }\end{array}$} & \multirow{2}{*}{$\begin{array}{l}\text { Energy } \\
\text { Yield }\end{array}$} & \multicolumn{3}{|c|}{ Elemental Analysis } \\
\hline & & & & & & & & C & $\mathbf{H}$ & $\mathbf{N}$ \\
\hline & $(\%)$ & $(\%)$ & $(\mathrm{kJ} / \mathrm{kg})$ & $(\mathrm{kJ} / \mathrm{kg})$ & $\begin{array}{c}(\mathbf{k g} \\
\text { d.m./m³ })\end{array}$ & & $(\%)$ & & $(\%)$ & \\
\hline FSW & 26.65 & 13.44 & $27.836 \pm 78$ & $26.598 \pm 75$ & $238.9 \pm 4.9$ & 1.724 & 46.0 & 71.47 & 1.50 & 1.61 \\
\hline A.pomace & 25.89 & 5.38 & $32.402 \pm 176$ & $30.948 \pm 168$ & $218.0 \pm 6.9$ & 1.526 & 39.5 & 80.18 & 1.82 & 2.08 \\
\hline B.pulp & 30.18 & 16.95 & $26.775 \pm 146$ & $25.572 \pm 139$ & $120.9 \pm 10.9$ & 1.635 & 49.4 & 68.54 & 1.19 & 1.87 \\
\hline BSG & 26.92 & 14.43 & $27.840 \pm 26$ & $26.465 \pm 25$ & $240.3 \pm 4.8$ & 1.372 & 36.9 & 69.75 & 1.63 & 6.42 \\
\hline Bark & 40.85 & 9.35 & $29.188 \pm 26$ & $28.142 \pm 26$ & $138.2 \pm 3.4$ & 1.495 & 61.1 & 79.34 & 1.58 & 0.52 \\
\hline MSW & 30.26 & 8.51 & $30.311 \pm 215$ & $28.974 \pm 206$ & $236.0 \pm 3.4$ & 1.617 & 48.9 & 79.06 & 1.62 & 1.55 \\
\hline
\end{tabular}




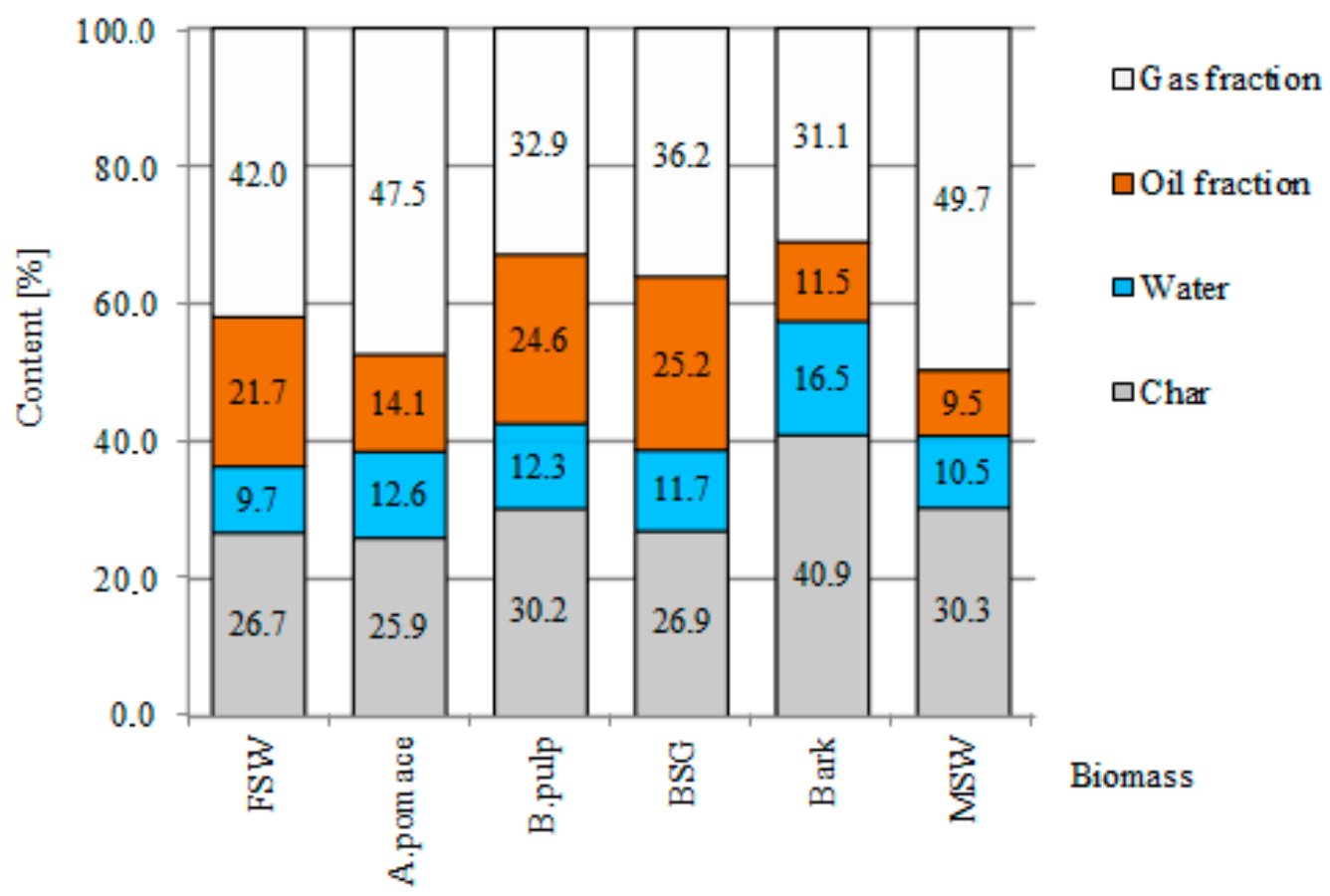

Figure 2. Solid, liquid and gaseous product distribution (wt.\%), expressed as average values, obtained with carbonization $\left(850^{\circ} \mathrm{C}\right)$.

Ash content reached values from $5.38 \%$ for A.pomace to $16.95 \%$ for B.pulp. Relative to the ash content in the raw materials, these values represent increments of $4.33 \%$ and $14.02 \%$, respectively. Similar results from the same thermochemical processes have been described by other authors, using municipal solid waste and biomass [15,16]. High ash biochars are of limited use as fuels in the combustion process, since they can cause excessive ash deposition or slag and contamination phenomena, leading to operational difficulties.

Differences in the elemental compositions of the biomasses and biochars resulting from carbonization clearly illustrate the effect of fuel refining, which involves the removal of water and the elimination of oxygen in the form of oxidized volatile compounds through decarboxylation, decarbonization and dehydration reactions.

To determine the energetic yield of the analyzed process, the energy densification ratio and energy yield were calculated (Equations (2) and (3)). The energy densification ratio, indicating the elevation in HHV during carbonization, differed in a narrow range from 1.372 to 1.724 , with a mean value of $1.5615 \pm 0.124$. However, energy densification does not indicate true changes in the energy value of the product, because it does not take into account the reduction in mass that occurs as a result of the process. When mass loss is considered, greater differences between the biomasses are revealed. The energy yield varied from $36.9 \%$ to $61.1 \%$ for BSG and bark, respectively. The mean value of the energy yield was $46.97 \% \pm 8.572 \%$. The biochars resulting from carbonization had a net calorific value of between 27 and $32 \mathrm{MJ} / \mathrm{kg}$. These values are comparable or even higher than good-quality milled coal (eco pea coal 24-26 MJ/kg, grain diameter 5-25 mm, produced from specially selected hard coal species to obtain fuel with low contents of sulfur and ash).

\subsubsection{Composition Analysis of Non-Condensable Gases}

Gaseous products are released during pyrolysis by the evaporation or thermal decomposition of the raw material. The amounts of emissions produced during thermal decomposition depend on the composition of the raw material, the heating rate, the temperature and the residence time. Table 3 shows the variations in the content and composition of volatile fractions. Figure 3 shows the variations in the content of hydrocarbons. The major gases produced from biomass carbonization were carbon dioxide and carbon monoxide. The content of $\mathrm{CO}_{2}$ decreased gradually, whereas the 
content of carbon oxide increased with the pyrolysis temperature (i.e., the time of the process), which is assumed to be the result of thermal decomposition in an oxygen-poor atmosphere. The high content of carbohydrates, cellulose, hemicellulose and lignin in the tested materials implies the formation of carbon dioxide, carbon monoxide and water, as a result of decarboxylation, decarbonization and dehydration reactions during thermal decomposition. More $\mathrm{CO}$ is produced at elevated temperatures and with longer residence time. The formation of $\mathrm{CO}$ is strongly affected by secondary reactions of low molecular weight products (especially aldehyde-type compounds) and $\mathrm{CO}_{2}$ is presumably produced in the early stage of cellulose pyrolysis, primarily in decarboxylation reactions [17-19].

Table 3. Chemical composition of non-condensable gases produced during the pyrolysis of biomass, expressed as average values. Content of compounds expressed as relative peak area (\%) of gases found in the fraction. $\mathrm{C}_{\mathrm{x}} \mathrm{H}_{\mathrm{y}}$-hydrocarbons, FSW-flavored spirits production waste (lime, grapefruit and lemon), B.pulp—beetroot pulp, A.pomace-apple pomace, BSG—brewer's spent grain, bark, MSW-municipal solid waste.

\begin{tabular}{|c|c|c|c|c|c|c|c|c|}
\hline \multirow{2}{*}{ Biomass } & \multirow{2}{*}{ Product } & 450 & 515 & 585 & 650 & 715 & 785 & 850 \\
\hline & & \multicolumn{7}{|c|}{$\left({ }^{\circ} \mathrm{C}\right)$} \\
\hline \multirow{6}{*}{ FSW } & $\mathrm{H}_{2}$ & 0.37 & 0.81 & 0.89 & 1.11 & 0.42 & 0.23 & 0.10 \\
\hline & $\mathrm{N}_{2}$ & 7.34 & 2.60 & 2.83 & 4.14 & 4.46 & 3.54 & 5.51 \\
\hline & $\mathrm{CO}$ & 35.82 & 39.9 & 39.46 & 35.29 & 38.34 & 43.49 & 42.95 \\
\hline & $\mathrm{CO}_{2}$ & 43.08 & 27.91 & 27.54 & 25.51 & 31.95 & 26.84 & 17.42 \\
\hline & $\mathrm{CH}_{4}$ & 6.33 & 14.69 & 16.16 & 19.06 & 14.62 & 15.06 & 16.52 \\
\hline & CxHy & 6.12 & 13.03 & 12.33 & 14.29 & 9.55 & 10.52 & 16.70 \\
\hline \multirow{6}{*}{ A.pomace } & $\mathrm{H}_{2}$ & 0.52 & 1.03 & 1.77 & 3.66 & 2.87 & 1.11 & 0.87 \\
\hline & $\mathrm{N}_{2}$ & 9.34 & 5.44 & 4.11 & 4.34 & 3.53 & 4.62 & 4.51 \\
\hline & $\mathrm{CO}$ & 28.22 & 22.49 & 23.20 & 23.88 & 32.27 & 35.63 & 39.85 \\
\hline & $\mathrm{CO}_{2}$ & 44.78 & 42.23 & 40.44 & 35.37 & 32.00 & 26.66 & 20.34 \\
\hline & $\mathrm{CH}_{4}$ & 8.87 & 14.66 & 15.11 & 15.22 & 15.33 & 16.66 & 17.01 \\
\hline & $\mathrm{CxHy}$ & 7.16 & 13.23 & 14.56 & 16.98 & 13.44 & 14.89 & 17.21 \\
\hline \multirow{6}{*}{ B.pulp } & $\mathrm{H}_{2}$ & 1.01 & 1.46 & 2.45 & 4.66 & 2.11 & 2.01 & 1.13 \\
\hline & $\mathrm{N}_{2}$ & 7.44 & 4.23 & 4.32 & 4.34 & 4.67 & 4.87 & 4.55 \\
\hline & $\mathrm{CO}$ & 19.59 & 13.44 & 12.57 & 13.95 & 24.36 & 24.86 & 22.39 \\
\hline & $\mathrm{CO}_{2}$ & 50.66 & 48.78 & 45.67 & 39.76 & 35.44 & 30.35 & 29.88 \\
\hline & $\mathrm{CH}_{4}$ & 10.6 & 15.38 & 17.66 & 18.67 & 20.11 & 21.46 & 22.65 \\
\hline & CxHy & 9.47 & 15.60 & 16.34 & 17.87 & 12.62 & 15.88 & 18.96 \\
\hline \multirow{6}{*}{ BSG } & $\mathrm{H}_{2}$ & 0.66 & 1.89 & 2.22 & 3.13 & 3.45 & 2.04 & 0.84 \\
\hline & $\mathrm{N}_{2}$ & 7.74 & 4.21 & 4.41 & 4.35 & 4.76 & 3.45 & 3.02 \\
\hline & $\mathrm{CO}$ & 28.09 & 29.33 & 30.55 & 31.95 & 34.57 & 37.59 & 43.33 \\
\hline & $\mathrm{CO}_{2}$ & 49.78 & 42.05 & 36.76 & 30.64 & 29.94 & 25.98 & 23.55 \\
\hline & $\mathrm{CH}_{4}$ & 6.25 & 10.07 & 11.01 & 12.15 & 12.77 & 13.53 & 13.88 \\
\hline & $\mathrm{CxHy}$ & 6.88 & 10.76 & 13.84 & 15.77 & 12.89 & 15.58 & 14.37 \\
\hline \multirow{6}{*}{ Bark } & $\mathrm{H}_{2}$ & 0.56 & 0.72 & 1.75 & 2.14 & 2.35 & 1.82 & 0.84 \\
\hline & $\mathrm{N}_{2}$ & 7.32 & 3.71 & 4.05 & 3.15 & 3.40 & 3.86 & 3.23 \\
\hline & $\mathrm{CO}$ & 26.21 & 35.11 & 29.54 & 27.85 & 28.72 & 32.75 & 38.37 \\
\hline & $\mathrm{CO}_{2}$ & 43.21 & 31.65 & 28.77 & 25.00 & 25.94 & 23.06 & 20.29 \\
\hline & $\mathrm{CH}_{4}$ & 11.08 & 14.28 & 17.84 & 19.8 & 20.99 & 19.58 & 18.26 \\
\hline & CxHy & 10.02 & 13.92 & 16.59 & 19.66 & 17.78 & 18.06 & 17.92 \\
\hline \multirow{6}{*}{ MSW } & $\mathrm{H}_{2}$ & 0.64 & 1.27 & 1.89 & 2.53 & 1.06 & 0.62 & 0.21 \\
\hline & $\mathrm{N}_{2}$ & 8.97 & 3.51 & 3.41 & 3.27 & 3.76 & 4.02 & 4.5 \\
\hline & $\mathrm{CO}$ & 29.25 & 33.34 & 31.75 & 30.89 & 33.84 & 37.59 & 40.59 \\
\hline & $\mathrm{CO}_{2}$ & 46.32 & 34.23 & 34.12 & 31.26 & 31.95 & 25.98 & 21.30 \\
\hline & $\mathrm{CH}_{4}$ & 7.25 & 13.25 & 14.78 & 15.85 & 15.23 & 16.29 & 16.87 \\
\hline & CxHy & 7.14 & 14.08 & 13.58 & 15.04 & 12.34 & 14.28 & 15.65 \\
\hline
\end{tabular}


The yields of $\mathrm{N}_{2}$ and $\mathrm{CH}_{4}$ were much lower than those for $\mathrm{CO}$ and $\mathrm{CO}_{2}$. Production of $\mathrm{N}_{2}$ was the highest in the initial part of the process of carbonization. At temperatures from $515^{\circ} \mathrm{C}$, only slight fluctuations were observed. There was also a small amount of methane, the concentration of which practically did not change at temperatures above $515^{\circ} \mathrm{C}$. Methane may be formed by methanation (the reaction of carbon with hydrogen oxide to obtain methane and water) at higher temperatures [20].

Based on the chemical compositions of the non-condensing gases, the values for combustion heat and net calorific value were calculated (Table 4). The LHV of the biomass increased with rising pyrolysis temperature. The most intense increase of LHV was observed in the first phase of the process, when the temperature reached $515{ }^{\circ} \mathrm{C}$. Bark and BSG were exceptions, in that a steady increase in LHV was observed up to $650{ }^{\circ} \mathrm{C}$. Further temperature changes up to $715^{\circ} \mathrm{C}$ did not have a major effect on LHV, which remained stable with some fluctuations. This was due to the pyrolysis reaction that occurred at higher temperatures. Following this stage of relative stabilization, LHV increased slightly again. These changes were the least pronounced in the case of bark and BGS. In the process of biomass thermal treatment, the major energy loss due to the release of volatile products took place in the torrefaction phase (up to $450^{\circ} \mathrm{C}$ ). The results for LHV show that non-condensing volatile products can be a valuable source of energy.

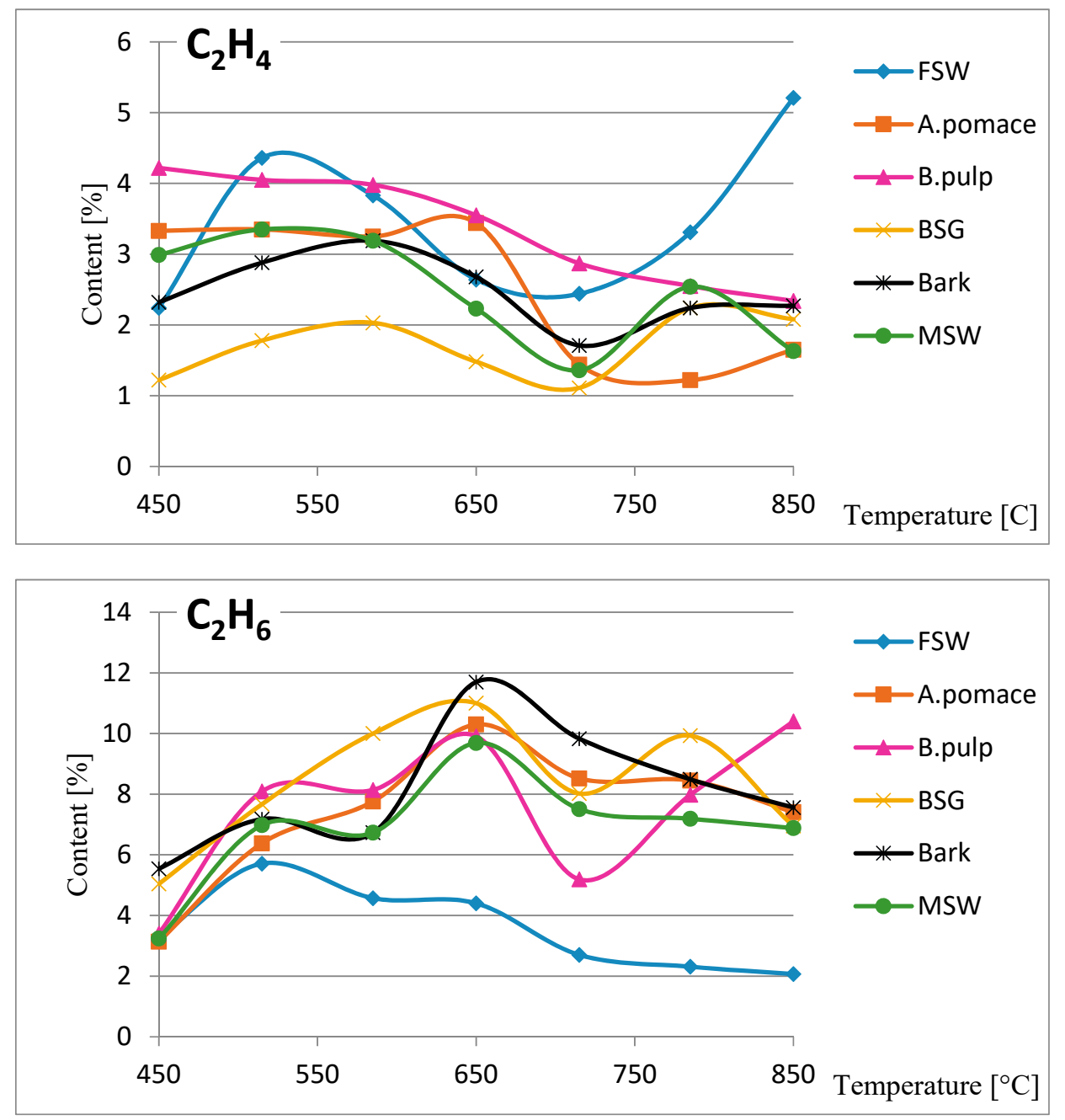

Figure 3. Cont. 

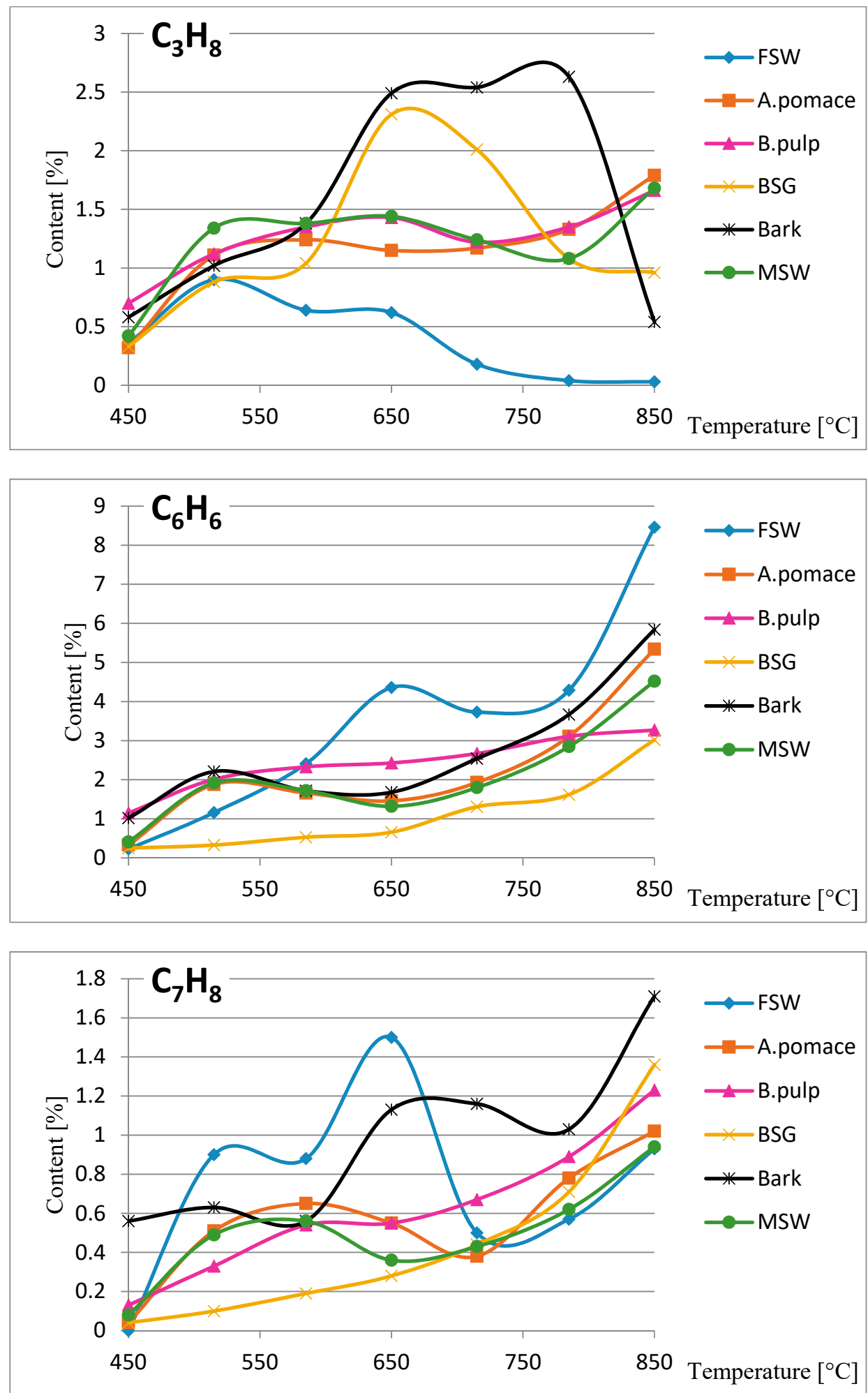

Figure 3. Volatile fractions produced during biomass pyrolysis as a function of temperature. FSW-flavored spirits production waste (lime, grapefruit and lemon), B.pulp-beetroot pulp, A.pomace—apple pomace, BSG—brewer's spent grain, bark, MSW—municipal solid waste. 
Table 4. Net calorific value (Lower Heating Value) (LHV) of non-condensable gases from pyrolysis of the analyzed biomasses, expressed as average values. $\mathrm{C}_{\mathrm{x}} \mathrm{H}_{\mathrm{y}}$-hydrocarbons, FSW-flavored spirits production waste (lime, grapefruit and lemon), B.pulp—beetroot pulp, A.pomace-apple pomace, BSG—brewer's spent grain, bark, MSW—-municipal solid waste.

\begin{tabular}{|c|c|c|c|c|c|c|}
\hline \multirow{2}{*}{\multicolumn{2}{|c|}{ Temperature FSW }} & \multicolumn{4}{|c|}{ Biomass } & \multirow{3}{*}{$\frac{\mathrm{MSW}}{\mathrm{MJ} / \mathrm{Nm}^{3}}$} \\
\hline & & A.pomace & B.pulp & BSG & Bark & \\
\hline${ }^{\circ} \mathrm{C}$ & $\mathrm{MJ} / \mathrm{Nm}^{3}$ & $\mathrm{MJ} / \mathrm{Nm}^{3}$ & $\mathrm{MJ} / \mathrm{Nm}^{3}$ & $\mathrm{MJ} / \mathrm{Nm}^{3}$ & $\mathrm{MJ} / \mathrm{Nm}^{3}$ & \\
\hline 450 & 10.905 & 11.589 & 13.388 & 10.512 & 15.135 & 11.284 \\
\hline 515 & 20.552 & 18.746 & 19.302 & 14.892 & 20.983 & 20.253 \\
\hline 585 & 21.471 & 19.942 & 21.114 & 17.628 & 21.088 & 20.286 \\
\hline 650 & 24.939 & 21.475 & 22.993 & 20.115 & 26.394 & 21.112 \\
\hline 715 & 19.507 & 20.565 & 21.481 & 19.486 & 26.486 & 19.806 \\
\hline 785 & 21.333 & 23.565 & 24.708 & 21.909 & 27.338 & 22.745 \\
\hline 850 & 29.170 & 27.729 & 27.259 & 23.568 & 29.158 & 25.970 \\
\hline
\end{tabular}

\subsubsection{Composition Analysis of Condensable Gases_Liquid Products}

The color and consistency of the condensates varied depending on the biomass. Images of the fractions are shown in the Supplementary Data (Figure S1). The condensates collected after A.pomace carbonization were distinctive. Their color was lighter and they did not look oily. Liquid phases collected from FSW and MSW were clearly darker than the others. They were oily and with a thicker consistency. As shown in Figure 2, the yield of condensates varied greatly, from 9.7\% to $25.2 \%$ for MSW and BSG, respectively. The composition of the condensate fractions from the thermal decomposition of biomass appeared to be very complex. Gas chromatography (GC) analysis revealed the presence of over 250 organic compounds (Figure S2, Supplementary Data). The main compounds were cresols, phenols, aromatic hydrocarbons (toluene, benzene, xylene), nitrous aromatic hydrocarbons, aliphatic ketones, furan derivatives and aromatic polycyclic hydrocarbons. The cresol and phenol contents were similar, ranging from $5.2 \%$ to $9.2 \%$ and from $5.3 \%$ to $8.7 \%$, respectively. The total content of benzene, toluene and xylenes ranged from $2.4 \%$ to $7.1 \%$. None of the organic compounds from the remaining groups occurred in quantities greater than $1 \%$. Polycyclic aromatic hydrocarbons were probably the product of the condensation of aromatic compounds, forming polycyclic structures [21]. The chemical pathways for cellulose pyrolysis and decomposition have been studied extensively $[19,22,23]$. According to the systematic review presented by Shen and Gu [19], furan and its furan derivatives are formed as a result of direct ring-opening and rearrangement reactions in cellulose molecules. As our results show, the condensates were composed of different organic compounds that can be recirculated and used as additives for other fuels, producing a positive impact on the environment. The elemental chemical composition values for bio-oils have been extensively reported in the literature [24]. The typical ranges for the products of fast pyrolysis are $50-60 \%$ for carbon, $6-9 \%$ for hydrogen, $30-40 \%$ for oxygen, $<0.5 \%$ for nitrogen and $<0.05 \%$ for sulfur [25].

\section{Conclusions}

Carbonization of agricultural waste biomass can be used to generate products with the composition and properties of alternative fuels. In this study, the thermochemical decomposition of waste biomaterials during rapid pyrolysis resulted in homogeneous biochar with yields of up to nearly $41 \%$ of the original mass. The biochars had much higher combustion heat and calorific values compared to the biomasses from which they were made. This was due to the fact they no longer contained water, which is physically and chemically bound to these biomasses and alternates in its chemical composition into products with higher carbon content. The biomass transformation process applied in this study enabled the moisture content to be lowered to such an extent that the addition of products no longer had a negative impact on the stability of the combustion process or the total combustion. As a consequence, the efficiency of the entire process was not affected. Both the non-condensable and condensate gaseous 
products were composed of various organic compounds with sufficiently high combustion heat and net calorific values that they could be recycled and used as additives in other fuels.

Supplementary Materials: The following are available online at http://www.mdpi.com/1996-1944/13/21/4971/s1, Figure S1: Photograph of the condensable gases-liquid products collected after pyrolysis of agricultural waste biomass. FSW—flavored spirits production waste (lime, grapefruit and lemon); B.pulp—-beetroot pulp; A.pomace-Applepomace; BSG—-brewer's spent grain; bark; MSW-municipal solid waste., Figure S2: GC-MS separation of organic compounds extracted to chloroform from the condensates obtained by carbonization of biomass. FSW-flavored spirits production waste (lime, grapefruit and lemon); B.pulp—beetroot pulp; A.pomace—Apple pomace; BSG—brewer's spent grain; bark; MSW-municipal solid waste.

Author Contributions: Conceptualization W.K. and P.D.; methodology, P.D. and M.A.B.; formal analysis M.A.B. and P.D.; investigation, M.A.B. and P.D.; resources, M.A.B.; data curation M.A.B.; writing-original draft preparation, M.A.B.; writing-review and editing, M.A.B. and P.D.; project administration W.K. and P.D.; funding acquisition, W.K. and P.D. All authors have read and agreed to the published version of the manuscript.

Funding: This study was financially supported by a grant from NCBiR (Polish National Centre for Research and Development) implemented within the project POIR.01.01.01-00-0374/17; Smart Growth Operational Programme -POIR in 2017; Priority axis I: Increased R\&D activity of enterprises (Badania przemysłowe i prace rozwojowe realizowane przez przedsiębiorstwa; Konkurs nr 2/1.1.1/2017). Titled: Innowacyjny system zwiększenia wykorzystania potencjału energetycznego paliwa oparty o układ skojarzonej gospodarki cieplnej i elektrycznej. zagospodarowujący energię odpadową niezbędną do zasilenia instalacji odbiorczych o różnych stanach energetycznych.

Conflicts of Interest: The authors declare no conflict of interest.

\section{References}

1. Goal 7: Sustainable Development Knowledge Platform. Available online: https://sustainabledevelopment. un.org/sdg7 (accessed on 9 December 2019).

2. Tripathi, M.; Sahu, J.N.; Ganesan, P. Effect of process parameters on production of biochar from biomass waste through pyrolysis: A review. Renew. Sustain. Energy Rev. 2016, 55, 467-481. [CrossRef]

3. Elkhalifa, S.; Al-Ansari, T.; Mackey, H.R.; McKay, G. Food waste to biochars through pyrolysis: A review. Resour. Conserv. Recycl. 2019, 144, 310-320. [CrossRef]

4. Lewandowski, W.M.; Ryms, M.; Kosakowski, W. Thermal Biomass Conversion: A Review. Processes 2020, 8, 516. [CrossRef]

5. Wilk, M.; Magdziarz, A. Hydrothermal carbonization, torrefaction and slow pyrolysis of Miscanthus giganteus. Energy 2017, 140, 1292-1304. [CrossRef]

6. Matali, S.; Rahman, N.A.; Idris, S.S.; Yaacob, N.; Alias, A.B. Lignocellulosic Biomass Solid Fuel Properties Enhancement via Torrefaction. Procedia Eng. 2016, 148, 671-678. [CrossRef]

7. Proskurina, S.; Heinimö, J.; Schipfer, F.; Vakkilainen, E. Biomass for industrial applications: The role of torrefaction. Renew. Energy 2017, 111, 265-274. [CrossRef]

8. Ciolkosz, D.; Wallace, R. A review of torrefaction for bioenergy feedstock production. Biofuels Bioprod. Biorefin. 2011, 5, 317-329. [CrossRef]

9. Available online: https://www.parrinst.com/wp-content/uploads/downloads/2013/07/483M_Parr_Intro-toBomb-Calorimetry.pdf (accessed on 29 October 2020).

10. Gowman, A.C.; Picard, M.C.; Rodriguez-Uribe, A.; Misra, M.; Khalil, H.; Thimmanagari, M.; Mohanty, A.K. Physicochemical analysis of Apple and Grape Pomaces. BioResources 2019, 14, 3210-3230.

11. Cantero-Tubilla, B.; Cantero, D.A.; Martinez, C.M.; Tester, J.W.; Walker, L.P.; Posmanik, R. Characterization of the solid products from hydrothermal liquefaction of waste feedstocks from food and agricultural industries. J. Supercrit. Fluids 2018, 133, 665-673. [CrossRef]

12. Wilk, B. Określenie zależności wartości opałowej od wybranych właściwości fizykochemicznych biomasy (Determination of dependence of the calorific value on selected physicochemical properties of biomass). In Mat. Seminar. Techniki Analityczne i Procedury Badawcze w Zastosowaniu do Nowych Uwarunkowań Prawnych $w$ Energetyce (Analytical Techniques and Research Procedures for Application to New Legislative Conditions in the Energy Sector); IChPW: Zabrze, Poland, 2006.

13. Tumuluru, J.S.; Hess, J.R.; Boardman, R.D.; Wright, C.T.; Westover, T.L. Formulation, pretreatment, and densification options to improve biomass specifications for Co-firing high percentages with coal. Ind. Biotechnol. 2012, 8, 113-132. [CrossRef] 
14. Jagustyn, B.; Bątorek-Giesa, N.; Wilk, B. Ocena właściwości biomasy wykorzystywanej do celów energetycznych. Chemik 2011, 65, 557-563.

15. Nobre, C.; Alves, O.; Longo, A.; Vilarinho, C.; Gonçalves, M. Torrefaction and carbonization of refuse derived fuel: Char characterization and evaluation of gaseous and liquid emissions. Bioresour. Technol. 2019, 285, 121325. [CrossRef]

16. Białowiec, A.; Pulka, J.; Stępień, P.; Manczarski, P.; Gołaszewski, J. The RDF/SRF torrefaction: An effect of temperature on characterization of the product-Carbonized Refuse Derived Fuel. Waste Manag. 2017, 70, 91-100. [CrossRef]

17. Shafizadeh, F.; Lai, Y.Z. Thermal Degradation of 1,6-Anhydro- $\beta$-D-glucopyranose. J. Org. Chem. 1972, 37, 278-284. [CrossRef]

18. Li, S.; Lyons-Hart, J.; Banyasz, J.; Shafer, K. Real-time evolved gas analysis by FTIR method: An experimental study of cellulose pyrolysis. Fuel 2001, 80, 1809-1817. [CrossRef]

19. Shen, D.K.; Gu, S. The mechanism for thermal decomposition of cellulose and its main products. Bioresour. Technol. 2009, 100, 6496-6504. [CrossRef]

20. Wahid, F.R.A.A.; Harun, N.H.H.M.; Rashid, S.R.M.; Samad, N.A.F.A.; Saleh, S. Physicochemical property changes and volatile analysis for torrefactionn of oil palm frond. Chem. Eng. Trans. 2017, 56, 199-204.

21. Richter, H.; Howard, J.B. Formation of polycyclic aromatic hydrocarbons and their growth to soot-a review of chemical reaction pathways. Prog. Energy Combust. Sci. 2000, 26, 565-608. [CrossRef]

22. Piskorz, J.; Radlein, D.; Scott, D.S. On the mechanism of the rapid pyrolysis of cellulose. J. Anal. Appl. Pyrolysis 1986, 9, 121-137. [CrossRef]

23. Kawamoto, H.; Morisaki, H.; Saka, S. Secondary decomposition of levoglucosan in pyrolytic production from cellulosic biomass. J. Anal. Appl. Pyrolysis 2009, 85, 247-251. [CrossRef]

24. Oyebanji, J.A.; Okekunle, P.O.; Lasode, O.A.; Oyedepo, S.O. Chemical composition of bio-oils produced by fast pyrolysis of two energy biomass. Biofuels 2018, 9, 479-487. [CrossRef]

25. Broumand, M.; Albert-Green, S.; Yun, S.; Hong, Z.; Thomson, M.J. Spray combustion of fast pyrolysis bio-oils: Applications, challenges, and potential solutions. Prog. Energy Combust. Sci. 2020, 79, 100834. [CrossRef]

Publisher's Note: MDPI stays neutral with regard to jurisdictional claims in published maps and institutional affiliations.

(C) 2020 by the authors. Licensee MDPI, Basel, Switzerland. This article is an open access article distributed under the terms and conditions of the Creative Commons Attribution (CC BY) license (http://creativecommons.org/licenses/by/4.0/). 